\title{
Lophira lanceolata protects testicular and spermatological damages induced by cisplatin in male Wistar rats
}

\author{
Solomon Tsekohol Agu*, Christian Okechukwu Ezihe, Paul Friday Itodo and Hyacinth Adakole Abu
}

\begin{abstract}
s
Background: Chemotherapy is associated with male infertility. Cisplatin (CP), an antineoplastic agent has been successfully used for the treatment of diverse kinds of malignancies, however, the use of this effective agent could induce oxidative stress injury, nephrotoxicity, hepatotoxicity, and testicular damage. Combined CP chemotherapy with plant extracts can diminish the toxicity and enhance the antitumor efficacy of the drug. The objective of the study was to determine the protective effect Lophira lanceolata leaf extract (LLLE) on CP-induced toxicity on male reproductive organs.
\end{abstract}

Methods: The study was carried out with $30(n=30)$ male Wistar rats (Rattus norvegicus). The rats were randomly assigned into 6 groups of 5 rats each. Rats in group 1 (Control) were administered distilled water per os. Rats in group 2 were administered $5 \mathrm{mg} / \mathrm{kg}$ of CP intraperitoneally (i.p). Rats in groups 3 and 4 were administered per os LLLE at the doses of 200 and $400 \mathrm{mg} / \mathrm{kg}$ body weight and rats in groups 5 and 6 were administered $5 \mathrm{mg} / \mathrm{kg}$ body weight of CP + LLLE at the doses of 200 and $400 \mathrm{mg} / \mathrm{kg}$ body weight respectively.

Results: The results showed a significant decrease in the sperm parameters in the group treated with CP alone when compared with the control and there in the sperm parameters in the groups administered CP + LLLE. The body and organ weights of the rats were significantly $(p<0.05)$ decreased in the CP treated group relative to the control. However, there was an increase in the weight of the organs in the LLLE pretreated groups. The photomicrographs showed degenerative changes in the testicular tissues of the rats administered CP alone whereas the group pretreated with the LLLE showed amelioration induced by the CP. Our study revealed that CP treatment has deleterious effects on sperm parameters and testicular tissues and the accessory sex organs (Epididymis, prostate, seminal vesicles) of the rats. Oral administration of LLLE at 200 and $400 \mathrm{mg} / \mathrm{kg}$ bodyweight for 26 days conferred protective effects against testicular damage induced by CP.

Conclusion: This study revealed that pretreatment with LLLE protected against CP-induced testicular toxicity.

Keywords: Cisplatin, Lophira lanceolata, Spermatozoa, Reproductive organ, Toxicity

\footnotetext{
* Correspondence: agusolomon84@yahoo.com

Department of Veterinary Physiology and Biochemistry, Federal University of Agriculture, Makurdi, Benue State, Nigeria
}

(c) The Author(s). 2020 Open Access This article is licensed under a Creative Commons Attribution 4.0 International License, which permits use, sharing, adaptation, distribution and reproduction in any medium or format, as long as you give appropriate credit to the original author(s) and the source, provide a link to the Creative Commons licence, and indicate if changes were made. The images or other third party material in this article are included in the article's Creative Commons licence, unless indicated otherwise in a credit line to the material. If material is not included in the article's Creative Commons licence and your intended use is not permitted by statutory regulation or exceeds the permitted use, you will need to obtain permission directly from the copyright holder. To view a copy of this licence, visit http://creativecommons.org/licenses/by/4.0/. 


\section{Introduction}

Chemotherapy involves the elimination of cancer cells or halting the growth of uncontrolled proliferative cells even at distant sites from the origin of the primary tumour by the use of chemical agents. Conversely, it does not discriminate between cancer and normal cells and destroys not only the rapid-growing cancer cells but also other rapidly dividing cells in the body [1]. Cisplatin, cis43 diamminedichloroplatinum (CDDP), with the molecular formula cis- $\left[\mathrm{Pt}\left(\mathrm{NH}_{3}\right)_{2} \mathrm{Cl}_{2}\right]$ is an antineoplastic agent that has been efficaciously used for management of different types of cancers including bladder, lung, neck, head, and testicular cancers [2]. CP is a block of efficient platinum-derived alkylating agent that acts against proliferating and resting cells [3] by inducing DNA crosslinks and DNA double-strand breaks; both of these activities cause suppression in DNA transcription and replication, leading to apoptosis [4]. It is undoubtedly known that $\mathrm{CP}$ is a proven antineoplastic drug used to combat cancers including sarcomas, however, nephrotoxicity, hepatotoxicity, oxidative stress injury and testicular damage are amongst the utmost feared side-effects for patients embarking on cancer chemotherapy [5]. The testis is an organ with high proliferative capacity and it is involved in the transfer of genetic material from one generation to the other, thus adverse effects of chemotherapy on the testes can be very devastating [6]. Gonadotoxicity with deterioration in sperm parameters (motility, count, and viability), inhibition of spermatogenesis, testicular atrophy, and reduced fecundity as a sequel to $\mathrm{CP}$ administration have been proven in several studies [7]. There is relative spermiotoxicity with the use of $\mathrm{CP}$ and almost all patients under chemotherapy show temporary or permanent azoospermia [8]. The mechanism underlying $\mathrm{CP}$-induced testicular injury involves biochemical and physiological tissue disturbances consequential to the formation of reactive oxygen species (ROS) and reactive nitrogen species (RNS) [9] that enhance cellular damage and necrosis via lipid peroxidation of tissues, DNA lesions, and protein denaturation [10].

Many natural products of plant origin safeguard against drug-induced toxicity [11]. Herbal medicine is gaining importance day-by-day in the management of several disorders, however, to date, just minimal information exists on medicinal plants that are described to relieve CP-induced reproductive side effects as a result of chemotherapy and new approaches to improve tolerance and reduce sequelae of cancer chemotherapy are urgently needed.

Iron wood (Lophira lanceolata) is a tree that is socioeconomically and culturally valuable to inhabitants of Africa and it is a traditional medicine recipe that has been used to treat several disorders. Earlier scientific reports on the leaf extract of this plant show that it possesses antibacterial [12] and antiplasmodial [13] activities. Decoctions of fresh/dried young leaves can treat pain caused by intestinal worms, dysentery, and diarrhoea for children. Women take the decoction of roots against menstrual pain, intestinal disorders, and malaria [14, 15] reported that its flowers are effective for treating several ailments including sexual weakness, epilepsies, yellow fever, and several others. Although, Lophira lanceolate is believed to have aphrodisiac properties and has been used in the management of sexual dysfunction, however, to the best of our knowledge, its ameliorative or protective effect against $\mathrm{CP}$-induced reproductive toxicity has not been investigated. We therefore aimed at evaluating the protective effects of LL in CP treated male Wistar rats. To achieve this, we evaluated spermatogenesis, organo-somatic indices (OSI) of the testes, seminal vesicles, prostate and epididymis along with the histopathological alterations in the testis of the experimental rat models.

\section{Materials and method}

The drug used for the induction of testicular and spermatological damages

The CP used was obtained from Kwality pharmaceuticals Pvt. Ltd. Nag Kalan, Majitha Road, Amritsar- India.

\section{Plant collection and preparation}

Fresh leaves of Lophira lancoelata were collected from within the premises of the Federal University of Agriculture, Makurdi, Benue State, Nigeria, and identified by a botanist. A voucher specimen (UAM/ $\mathrm{FH} / 0328$ ) has been deposited in the Herbarium of the College of Forestry, Federal University of Agriculture, Makurdi. The leaves were collected and washed under running tap water and air-dried under room temperature for two (2) weeks. The dried leaves were pulverized with a kitchen electric grinding machine and stored in an airtight container. About $200 \mathrm{~g}$ of smooth powdered leaves of Lophira lancoelata were placed in a conical flask containing $4000 \mathrm{ml}$ of distilled water. This was kept at room temperature for $48 \mathrm{~h}$ with frequent agitation every 2 h. Filtration was done with a Whatman ${ }^{\mathrm{nt}}$ no. 1 filter at the end of the period. The filtrate was concentrated by evaporating at $45^{\circ} \mathrm{C}$ using a water bath. The concentrated extract was weighed to determine the yield and stored in the refrigerator until needed.

Experimental animal management and treatment Adult male Wistar strain albino rats (150-230 g) were obtained from Animal house, College of medicine, 
Benue State University, Makurdi. The rats were kept in standard cages in a well-ventilated laboratory animal house under controlled temperature $\left(24 \pm 27^{\circ} \mathrm{C}\right)$ and photoperiod (12 L,12D).and were fed with Growers Mash $^{\circ}$ produced by Grand Cereals and Oil Mills Ltd. Bukuru, Jos. The rats were acclimatized for 14 days to the best laboratory conditions before the experiment were provided with a balanced diet, water was provided ad libitum. The experimental protocol was by the guidelines on the care and wellbeing of research animals [16] and was approved by the Departmental Ethics Committee with an assigned number (VPB/01/03/2019). The rats were handled according to the standard protocols for the use of laboratory animals for experiments.

Thirty (30) male albino rats weighing 150-230 g were recruited in this study. The rats were randomly assigned to 6 groups of five rats in each group. Group 1 rats received distilled water only orally for 26 days. Groups 2 rats were given distilled water for 20 days orally and on day 21 the rats were treated with $\mathrm{CP}$ at a dose of $5 \mathrm{mg} / \mathrm{kg}$ intraperitoneally (i.p). Groups III and IV were administered doses of LLLE 200 and $400 \mathrm{mg} / \mathrm{kg}$ body weight (bwt) respectively for 26 days. Groups V and VI were administered doses LLLE at 200 and $400 \mathrm{mg} / \mathrm{kg}$ body weight respectively for 26 days and the same rats were treated with CP 5 $\mathrm{mg} / \mathrm{kg}$ on the $21 \mathrm{st}$ day as in group II. The body weights of the experimental rats were recorded weekly.

\section{Collection and preparation of tissues}

About $24 \mathrm{~h}$ after the last treatments, the rats were anesthetized with pentobarbitone sodium (PS) at a dose of $60 \mathrm{mg} / \mathrm{kg}$ i.p. The testes and accessory organs of each rat were collected and weighed using a Mettler meter. Epidydimal sperm was collected by cutting one epididymis into small pieces in $5 \mathrm{ml}$ of physiological saline at room temperature. The testes were preserved in $10 \%$ formalin for histopathological analysis.

\section{Sperm parameters}

Determination of Epidydimal sperm motility A sperm motility test was carried out using the method described by the World Health Organization [17]. The individual motility was determined by the formula;

$$
\text { Motility (individual) }(\%)=\frac{\text { Number of motile sperm }}{\text { Total no.of sperm }(\text { motile }+ \text { immotile })} \times 100
$$

Determination of Epidydimal sperm viability Sperm viability test was determined by the method described by the $[17,18]$.

The sperm viability was calculated as given below
Viable $(\%)=\frac{\text { numberofviablesperm }}{\text { totalno.ofsperm }(\text { viable }+ \text { non }- \text { viable })} \times 100$

Determination of sperm concentration Sperm concentration of each sample was determined using the improved Neubauer haemocytometer after dilution in $0.9 \%$ normal-saline [19].

Determination of acrosome integrity The sperm acrosome integrity was determined by the method described by [20].

Acrosome integrity was determined by placing a drop $(100 \mu \mathrm{L})$ of sperm sample on a clean, grease-free slide and mixed with a single drop of Giemsa stain. The spermatozoa were allowed to interact with the stain for at least $2 \mathrm{~min}$ and then a smear was prepared. The prepared smear was air-dried and examined under oil immersion objective (100x magnification) to determine the percentage of spermatozoa with intact acrosomes. The spermatozoa that pick the Eosin-Nigrosine stain means Acrosome integrity is compromised or dead. The spermatozoa with intact Acrosome integrity does not pick the stain. The mean results were expressed as percent intact acrosomes.

Determination of sperm morphology Sperm morphology was determined by the method described by [17].

The sperm cells were scored as follows:

Normal morphology: sperms with normal head and tail. Abnormal morphology: sperm cells with isolated heads - misshapen head or not; head misshapen head with abnormal tail and fused sperm. The percentage of abnormal forms were evaluated; Normal semen has fewer than 30\% abnormal forms [21].

\section{Histological analyses of the testicular tissues}

Histopathological examination was carried out according to the method described by [22]. The testicular tissues were fixed in $10 \%$ formalin, dehydrated, embedded in paraffin, sectioned, and stained with hematoxylin and eosin. The stained-glass slides were viewed under a light microscope at $\times 100$.

\section{Statistical analysis}

Results are expressed as mean \pm standard error of mean (Mean \pm SEM). The data were analyzed by one-way analysis of variance (ANOVA). All statistical analysis was carried out using Graph Pad Prism Version 6.1 for windows. 


\section{Results}

Protective effects of LLLE on the bodyweight of Wistar rat treated with $\mathrm{CP}$

Table 1 shows the initial body weight, final body weight, and weight gain of the experimental rats.

Accordingly, the loss in body weight of the rats was greater in the groups administered CP and CP+ LLLE) than in the control group. There was a significant $(p<0.05)$ decrease in body weight in the group treated with $\mathrm{CP}$ only when compared with the controls, however, there was an increase in the body weights in the groups co-administered CP + LLLE in a dose-dependent manner.

\section{Effects of LLLE on the sperm parameters in albino rats}

Treatment of rats with LLLE alone at graded doses did not affect the parameters studied as compared to the control value. Administration of $\mathrm{CP}$ alone caused a significant decrease in sperm motility, sperm concentration, and a significant increase in the percentage of abnormal sperm and acrosomal integrity (dead) when compared to the control group. Pretreatment of the rats with LLLE for 21 days before CP treatment significantly showed an increase in the percentage motility (Table 2).

\section{Histopathological slide of the testis of Wistar rats treated with LLLE and CP (Table 3)}

\section{Summary of the slides}

A: Histopathological slide of the testes in the normal control group (group 1) showing normal seminiferous tubule and normal germinal epithelium. X100 magnification

B: Histopathological slides of the testes of rats in the Cisplatin treated group (group 2) show atrophic and degenerative seminiferous tubules and lots of degenerated spermatozoa. X100 magnification

C: Histopathological slides of the testes of rats in LLLE $200 \mathrm{mg} / \mathrm{kg}$ treated group (group 3) showing normal seminiferous tubule and normal germinal epithelium

D: Histopathological slides of the testes of rats in LLLE $400 \mathrm{mg} / \mathrm{kg}$ treated group (group 4) showing congested blood vessels, normal seminiferous tubules, and normal spermatozoa. X100 magnification

E: Histopathological slides of the testes of rats treated with LLLE at 200mg/kg + CP (group 5) showing restored seminiferous tubules towards normality. X100 magnification

F: Histopathological slides of the testes of rats treated with LLLE at 400mg/kg + CP (group 6) showing restored degenerative changes in the seminiferous tubules towards normality. X100 magnification.

\section{Discussion}

One of the mammalian tissues reported to be the most susceptible to CP toxicity is the germ cells. CP treatment has been reported to induce oxidative stress with damaging consequences on the testes and DNA resulting in infertility and hence, there is a need, therefore, to avert such side effects to preserve the testicular tissues of patients undergoing CP treatment [7]. The results of the present study suggested that $\mathrm{CP}$ treatment is very deleterious to the male reproductive organ and LLLE showed a cytoprotective function in the rat's testicular tissues. These data are confirmed by our observation of the increased reproductive organ weights, improved spermatological parameters, and histopathological examination.

The results of the present study showed that the treatment with CP causes a reduced body weight gain process [23] in their previous work reported that the two most serious health problems in patient chemotherapy, especially with CP are depressed appetite and consequent weight loss may be due to reduced feed efficiency. Conversely, an increase in body weight was

Table 1 Protective effect of oral administration of LLLE for 26 days on body weight of Male Wistar rats treated with CP

\begin{tabular}{|c|c|c|c|c|c|}
\hline Groups & Initial body weights (g) & weight at $2^{\text {nd }}$ week & weight at $3^{\text {rd }}$ week & final body weight (g) & Weight gain \\
\hline Dist Water & $158.6 \pm 6.14$ & $172.8 \pm 12.08$ & $179.0 \pm 12.81$ & $195.0 \pm 10.37$ & 37 \\
\hline $\mathrm{CP}$ & $170.8 \pm 4.36$ & $181.6 \pm 3.92$ & $191.0 \pm 5.20$ & $184.8 \pm 7.10$ & 13 \\
\hline $\begin{array}{l}\text { LLLE } \\
200 \mathrm{mg}\end{array}$ & $171.8 \pm 4.41^{b}$ & $186.0 \pm 7.15^{b}$ & $190.8 \pm 5.12^{b}$ & $195.4 \pm 5.27^{b}$ & 24 \\
\hline $\begin{array}{l}\text { LLLE } \\
400 \mathrm{mg}\end{array}$ & $174.6 \pm 2.69^{b}$ & $186.6 \pm 2.44^{b}$ & $195.0 \pm 2.61$ & $198.6 \pm 6.21$ & 24 \\
\hline $\begin{array}{l}\text { CIS+LLLE } \\
200 \mathrm{mg})\end{array}$ & $190.4 \pm 5.19^{\mathrm{ab}}$ & $198.8 \pm 4.88^{b}$ & $206.4 \pm 7.20$ & $209.0 \pm 7.38$ & 19 \\
\hline $\begin{array}{l}\text { CIS+LLLE } \\
400 \mathrm{mg}\end{array}$ & $181.0 \pm 3.26^{b}$ & $193.6 \pm 2.58^{b}$ & $200.4 \pm 3.53$ & $201.4 \pm 3.49^{b}$ & 20 \\
\hline
\end{tabular}

Note: The values are presented as Means \pm SEM, $(n=5)^{\text {a }}$ Significant Differences as compared with normal control group $p<0.05{ }^{b}$ Significant Differences as compared with the negative control group at $p<0.05$ 
Table 2 Protective effect of oral administration of LLLE for 26 days on the weight of the relative organs in Wistar male rats treated with $C P$

\begin{tabular}{llllllll}
\hline Groups & Testes (left) & Testes (right) & Sem.v (left) & Sem.v (right) & Epid. (left) & Epid. (right) & Prostate \\
\hline Dist water & $0.63 \pm 0.01$ & $0.62 \pm 0.01$ & $0.18 \pm 0.01$ & $0.16 \pm 0.01$ & $0.23 \pm 0.01$ & $0.22 \pm 0.01$ & $0.06 \pm 0.002$ \\
CP & $0.31 \pm 0.03$ & $0.30 \pm 0.03$ & $0.04 \pm 0.002$ & $0.03 \pm 0.002$ & $0.15 \pm 0.01$ & $0.14 \pm 0.008$ & $0.04 \pm 0.005$ \\
(LLLE200m) & $0.61 \pm 0.02^{\mathrm{b}}$ & $0.60 \pm 0.02^{\mathrm{b}}$ & $0.06 \pm 0.005^{\mathrm{a}}$ & $0.05 \pm 0.005^{\mathrm{a}}$ & $0.24 \pm 0.01^{\mathrm{b}}$ & $0.23 \pm 0.001^{\mathrm{b}}$ & $0.06 \pm 0.006$ \\
(LLLE 400mg) & $0.60 \pm 0.01^{\mathrm{b}}$ & $0.59 \pm 0.01^{\mathrm{b}}$ & $0.10 \pm 0.02$ & $0.09 \pm 0.02$ & $0.21 \pm 0.009^{\mathrm{b}}$ & $0.20 \pm 0.007^{\mathrm{b}}$ & $0.06 \pm 0.009$ \\
(CP+ LLLE 200mg) $^{\mathrm{a}}$ & $0.49 \pm 0.03^{\mathrm{ab}}$ & $0.47 \pm 0.03^{\mathrm{ab}}$ & $0.10 \pm 0.02$ & $0.09 \pm 0.02$ & $0.20 \pm 0.008$ & $0.19 \pm 0.009$ & $0.06 \pm 0.003$ \\
(CP+ LLLE 400mg) $^{\mathrm{b}}$ & $0.49 \pm 0.02^{\mathrm{ab}}$ & $0.48 \pm 0.02^{\mathrm{ab}}$ & $0.16 \pm 0.03^{\mathrm{b}}$ & $0.14 \pm 0.03^{\mathrm{b}}$ & $0.15 \pm 0.01^{\mathrm{a}}$ & $0.14 \pm 0.01^{\mathrm{a}}$ & $0.08 \pm 0.007^{\mathrm{b}}$ \\
\hline
\end{tabular}

Note: The values are presented as Means \pm SEM $(n=5)^{\mathrm{a}}$ Significant Differences as compared with normal control group $p<0.05^{\mathrm{b}}$ Significant Differences as compared with the negative control group at $p<0.05$

observed in the groups co-administrated CP and LLLE, and this may suggest that LLLE administration improved the appetite of the rats thereby abrogating the anorexic effect induced by CP treatment. To our knowledge, this is the first report of LLLE on the prevention of cisplatininduced weight loss. In this study, the relative reproductive organ weights of male rats exposed to $\mathrm{CP}$ was significantly $(p<0.05)$ reduced when compared to control group, the decline in the reproductive organ weight was mitigated by co-administered of CP and LLLE at 200 $\mathrm{mg} / \mathrm{kg}$ and $400 \mathrm{mg} / \mathrm{kg}$ in group 5 and 6 respectively. The therapeutic amelioration could be attributed to the Phytochemicals present in the LLLE that abrogated the effect of the $\mathrm{CP}$ on the reproductive organs. Our present findings on $\mathrm{CP}$ induced testicular impairment also endorsed the earlier findings of [24] who reported that a notably reduced testes and accessory sex organs weight in rats administered CP. Also, the prior work of [25] has confirmed that $\mathrm{CP}$ caused a decline in the body, testicular, epididymis, and seminal vesicle weights in experimental rats. There are reports of biochemical and testicular tissue alterations such as in germinal epithelium and long-term failure of spermatogenesis due to its alkylation property following CP treatments [26].

The epididymis is an essential structural part of the testis conferring fecundity capacity on the spermatozoa and the development of rapid progressive motility. It is understood that certain anomalies may originate from this critical region [27]. Cisplatin treatment alone significantly $(p<0.05)$ resulted in caudal epididymal sperm morphological abnormalities when compared with the control. This result is consistent with [7] who established that the toxicity effects caused by $\mathrm{CP}$ treatment include a decrease in sperm count, alteration in sperm motility, and an increase in abnormal sperm ratios. This is in agreement with previous reports on platinum compounds in humans [28] and animal $[29,30]$ also reported that the percentage of normal sperm cells was decreased in mice treated with a single dose of CP.

Furthermore, in experimental animals, acute exposure to chemotherapeutic agents like CP has revealed an increase in the occurrence of germ-cell apoptosis. It can also lead to decreased reproductive organ weights, azoospermia, and degenerated spermatogenic cells [31, 32]. In the current study, the fertilizing ability of the $\mathrm{CP}$ treated group (group 2) was significantly reduced. The reduction in fertility of the rats could be due to high percentages of deformed/abnormal sperm cells (headless, bent sperm, and tailless sperm) as compared to the control. However, the spermatozoa recovered from the cauda epididymis of the rats in groups 5 and 6, co-administered CP and LLLE at 200 and $400 \mathrm{mg} / \mathrm{kg}$

Table 3 Protective effects of oral administration of LLLE for 26 days on sperm parameters of CP treated male Wistar rats

\begin{tabular}{llllllll}
\hline Groups & $\begin{array}{l}\% \text { Sperm } \\
\text { motility }\end{array}$ & $\begin{array}{l}\% \text { Sperm } \\
\text { viability }\end{array}$ & $\begin{array}{l}\text { Sperm } \\
\text { conc. }\end{array}$ & $\begin{array}{l}\text { Acrosome integrity } \\
\text { (live) }\end{array}$ & $\begin{array}{l}\text { Acrosome Integrity } \\
\text { (dead) }\end{array}$ & $\begin{array}{l}\text { Sperm Morp. } \\
\text { (normal) }\end{array}$ & $\begin{array}{l}\text { Sperm morp. } \\
\text { (abn) }\end{array}$ \\
\hline Dist water & $66.0 \pm 2.45$ & $65.2 \pm 2.24$ & $5.40 \pm 0.18$ & $69.18 \pm 1.29$ & $31.27 \pm 1.67$ & $65.25 \pm 3.97$ & $34.75 \pm 3.97$ \\
CP & $40.0 \pm 4.47$ & $40.0 \pm 4.47$ & $3.95 \pm 0.20$ & $22.46 \pm 2.78$ & $77.54 \pm 2.78$ & $28.60 \pm 0.82$ & $71.40 \pm 0.82$ \\
LLLE 200mg & $88.6 \pm 1.86^{\mathrm{ab}}$ & $88.6 \pm 1.86^{\mathrm{ab}}$ & $9.65 \pm 0.15^{\mathrm{ab}}$ & $77.74 \pm 4.63^{\mathrm{b}}$ & $22.29 \pm 4.63^{\mathrm{b}}$ & $80.93 \pm 4.45^{\mathrm{ab}}$ & $19.06 \pm 4.45^{\mathrm{ab}}$ \\
LLLE 400mg & $81.25 \pm 2.39^{\mathrm{ab}}$ & $81.25 \pm 2.39^{\mathrm{ab}}$ & $7.44 \pm 0.40^{\mathrm{ab}}$ & $70.03 \pm 0.66^{\mathrm{b}}$ & $29.98 \pm 0.66^{\mathrm{b}}$ & $73.98 \pm 1.92^{\mathrm{b}}$ & $26.02 \pm 1.92^{\mathrm{b}}$ \\
(CIS+LLLE 200mg) & $73.0 \pm 3.00^{\mathrm{b}}$ & $73.0 \pm 3.00^{\mathrm{b}}$ & $7.70 \pm 0.29^{\mathrm{ab}}$ & $71.39 \pm 0.76^{\mathrm{b}}$ & $28.61 \pm 0.76^{\mathrm{b}}$ & $71.29 \pm 0.48^{\mathrm{b}}$ & $28.70 \pm 0.48^{\mathrm{b}}$ \\
(CIS+LLLE 400mg) & $80.24 \pm 3.15^{\mathrm{ab}}$ & $80.25 \pm 3.15^{\mathrm{ab}}$ & $8.44 \pm 0.39^{\mathrm{ab}}$ & $74.65 \pm 1.21^{\mathrm{b}}$ & $25.35 \pm 1.21^{\mathrm{b}}$ & $79.48 \pm 1.11^{\mathrm{ab}}$ & $20.52 \pm 1.11^{\mathrm{ab}}$ \\
\hline
\end{tabular}

Note: The values are presented as Means $\pm \operatorname{SEM},(n=5)^{\text {a }}$ Significant Differences as compared with normal control group $p<0.05^{\mathrm{b}}$ Significant Differences as compared with the negative control group at $p<0.05$ 
respectively have high percentages of normal sperm with head, body, and tail intact that can naturally ascend the female reproductive tract to the site of fertilization and also to achieve fertilization [33]. Though descriptions for the recorded abnormalities could be conjectural, however, the aberrations could have resulted from the abnormal chromosome, a slight modification in testicular DNA, or errors during the process of spermatogenesis [34]. The data from the present study shows that the treatment of rats with LLLE has the potential to improve the reproductive fitness of rats. Interestingly, treatment with LLLE alone at the dose of $200 \mathrm{mg} / \mathrm{kg}$ and 400 $\mathrm{mg} / \mathrm{kg}$ increased sperm count respectively. A corresponding increase in spermatozoa motility was also observed especially in the group treated with LLLE at $200 \mathrm{mg} / \mathrm{kg}$. These sperms were capable of forwarding movement needed for fertilization with no defects in flagella substructures.

The reproductive toxicity of $\mathrm{CP}$ was further substantiated by the histological analysis of the testes. Testicular sections of control (group) revealed copious seminiferous tubules that were regularly spaced with all cells of the spermatogenic series and interstitial spaces that were essentially normal (slide A). Conversely, rats exposed to CP (group 2) showed disruption of the normal architecture of the testes, e.g., testicular atrophy, degenerative changes in the seminiferous tubules, presence of spermatozoa (Headless and tailless spermatozoa, bent spermatozoa) and degenerative changes in spermatogonia cell lining the seminiferous tubules, associated with incomplete spermatogenesis (slide B). The results of this study are consistent with the findings of [35] in a similar study in which Wistar rats that were exposed to endosulfan, an organochlorine pesticide developed testicular atrophies [36] in another but akin study also established that the exposure of Wistar rats to chlorpyrifos for 30 days at various dosage levels caused degeneration in seminiferous tubule having decreased number of spermatogenic elements in exposed rats.

\section{Histological sections of LLLE alone (200 and $400 \mathrm{mg} / \mathrm{kg}$ ) did not show any deleterious changes in seminiferous tubular architecture and interstitium (slide $C$ and D)} There was a remarkable tissue restoration in the photomicrographs of rats in the groups that were coadministered CP + LLLE at $200 \mathrm{mg} / \mathrm{kg}$ and $400 \mathrm{mg} / \mathrm{kg}$ respectively. The photomicrographs showed the appearance of normal seminiferous tubules and interstitial spaces occupied by the Leydig cells. Most of the seminiferous tubules were close together with regular outlines and narrow interstitium (Slide E and F).

\section{Conclusion}

This result may suggest that LLLE exhibited a protective effect on the testicular tissues and could favour normal spermatogenesis in the seminiferous tubules of the testes of the rats which may be attributed to the phytochemicals it contains. This strengthens the medicinal use of this herb in managing reproductive related problems.

\section{Abbreviations \\ LLLE: Lophira lanceolata leaf extract; LL: Lophira lanceolata; CP: Cisplastin; CDDP: Cisplatin, cis-diamminedichloroplatinum; ip: Intraperitoneally; PS: Pentobarbitone sodium; Sem V: Seminal Vesicle; Epid: Epididymis; abn: Abnormal; Conc: Concentration; Morph: Morphology; SEM: Standard error of mean; ROS: Reactive oxygen species; RNS: Reactive nitrogen species; n: Number of animals; no: Number; ANOVA: One-way analysis of variance}

\section{Acknowledgements}

Not applicable.

Authors' contributions

The authors read and approved the final manuscript.

\section{Funding}

The research was fully funded by the authors.

\section{Availability of data and materials}

The data sets used and/or analyzed during the current study are available from the corresponding author on reasonable request.

\section{Ethics approval and consent to participate}

The protocols of this study were approved by the Animal Welfare and Ethics Committee of the College of Veterinary Medicine, Federal University of

Agriculture, Makurdi, Nigeria.

\section{Consent for publication}

Not applicable.

\section{Competing interests}

The authors declare that they have no competing interests.

Received: 11 March 2020 Accepted: 3 November 2020

Published online: 08 December 2020

\section{References}

1. Bonadonna G, Valagussa P, Moliterni A, Zambetti M, Brambilla C. Adjuvan Cyclophosphamide,Methotrexate, and fluorouracil in node-positive breast cancer: the results of 20 years of follow-up. N Engl J Med. 1995;332:901-6.

2. Moneim A. Azadirachta indica attenuates cisplatin-induced neurotoxicity in rats. Indian J Pharmacol. 2014;46(3):316-21.

3. Lirdi LC, Stupp T, Sasso-Cerri E, Miraglia SM. Amifostine protective effect on cisplatin treated rat testis. Anat Recd. 2008;291:797-808.

4. Reddy KP, Madhu P, Reddy PS. Protective effects of resveratrol against cisplatin-induced testicular and epididymal toxicity in rats. Food Chem Toxicol. 2016;91:65-72.

5. Yao X, Panichpisal K, Kurtzman N, Nugent K. Cisplatin nephrotoxicity: a review. Am J Med Sci. 2007;334:115-24.

6. Ghobadi E, Moloudizargari M, Asghari MH, Abdollahi M. The mechanisms of cyclophosphamide induced testicular toxicity and the protective agents. Expert Opin Drug Met. 2017;13:525-39.

7. Kaya K, Ciftci O, Cetin A, Doğan H, Başak N. Hesperidin protects testicular and spermatological damages induced by cisplatin in rats. Androl. 2015;47: 793-800.

8. Malarvizhi D, Mathur PP. Effects of cisplatin on testicular functions in rats. Indian J Exp Biol. 1996;34:995-8.

9. Azu OO, Duru FIO, Osinubi AA, Oremosu AA, Noronha CC, Elesha SO, Okanlawon AO. Histomorphometric effects of Kigelia africana (Bignoniaceae) fruit extract on the testis following short-term treatment with cisplatin in male Sprague-Dawley rats. Middle East Fert Soc J. 2010;15:200-8. 
10. Fallahzadeh AR, Rezaei Z, Rahimi HR, Barmak MJ, Sadeghi H, Mehrabi S, Rabani SM, Kashani IR, Barati V, Mahmoudi R. Evaluation of the effect of pentoxifylline on cisplatin-induced testicular toxicity in rats. Toxicol Res. 2017:33(3):255-63 https://doi.org/10.5487/TR.2017.33.3.255.

11. Atanasov AG, Waltenberger B, Pferschy-Wenzig EM, Linder $T$, Wawrosch C, Uhrin P, Temml V, Wang L, Schwaiger S, Heiss EH, Rollinger JM, Schuster D, Breuss JM, Bochkov V, Mihovilovic MD, Kopp B, Bauer R, Dirsch VM, Stuppner $\mathrm{H}$. Discovery and resupply of pharmacologically active plant-derived natural products: A review. Biotech Adv. 2015;33(8): 1582-614.

12. Audu S, Mohammed I, Kaita H. Phytochemical screening of the leaves of Lophira lanceolata (Ochnaceae). Life Sci J. 2007;4(4):75-9.

13. Collins AO, Peter AA, Chukwuemeka SN, Theophine CO, Florence NM, Ifeoma AN, Nelson O, Obinna O. Antiplasmodial and antioxidant activities of methanol extract of the fresh leaf of Lophira lanceolata (Ochnaceae). Afr J Biotech. 2014;13(16):1731-8.

14. Kouaro OM, Tasso F. LLLEdans la commune de Toucountouna: entre exploitation et conservation d'une espèce naturelle à usages multiples. Revue de géographie du Bénin. 2010;7:94-115

15. Aliou D, Honoré SSB, Armand KN, Gérard G. Quantitative ethnobotany of LLLETiegh. Ex Keay (Ochnaceae) in Benin (West Africa) Int. J. Biol. Chem Sci. 2017;11(3):1236-53.

16. National institute of Health (N.I.H). Guide for the care and use of laboratory animals. DHEW publication. Bethsaida; U.S.A: Office of science and Health Reports; 1985.

17. World Health Organization. WHO Laboratory manual for the examination of human semen and sperm-cervical mucus interaction. 4th ed. Cambridge: Cambridge University Press; 1999.

18. Gupta PC. Evaluation of Invitro spermicidal potentials of Mimusops elengi Linn. (Bukul) in wild mice. Indian J Sci. 2014;11(27):7-14.

19. Eljarah A, Chandler J, Jenkins JA, Chenevert J, Alcanal A. Usefulness of hemocytometer as a counting chamber in a computer-assisted sperm analyzer (CASA). Anim Reprod Belo Horizonte. 2013;10(4):708-11.

20. Dott HM, Foster GC. A technique for studying the morphology of mammalian spermatozoa which are eosinophilic in a differential live and dead stain. J Reprod Fertil. 1972;29:443-6.

21. Sood M. Textbook of Medical Laboratory Technology. 1st ed. New Delhi: Jaypee Brothers Medical Publishers; 2006. p. 199-219. 408-410; 615-646.

22. Choji TPP, Ngokere AA, Ogenyi SI, Kumbish PR. Histoarchitectural evaluation of conventional versus two rapid microwave processing techniques. $\mathrm{Br}$ Biotech J. 2015;8(3):1-19.

23. Garcia JM, Scherer T, Chen JA, et al. Inhibition of cisplatin-induced lipid catabolism and weight loss by ghrelin in male mice. Endocrinol. 2013;154: 3118-29.

24. Creasy DM. Evaluation of testicular toxicology: A synopsis and discussion of the recommendations proposed by the Society of Toxicologic Pathology. Birth Defects Res B Dev Reprod Toxicol. 2003;68:408-15.

25. Adejuwon SA, Femi-Akinlosotu OM, Omirinde JO. Cisplatin-induced testicular dysfunction and its amelioration by Launaea taraxacifolia leaf extract. Androlo. 2015;47:553-9

26. Aminsharifi A, Shakeri S, Ariafar A, Moeinjahromi B, Kumar PV Karbalaeedoost S. Preventive role of exogenous testosterone on cisplatininduced gonadal toxicity: an experimental placebo-controlled prospective trial. Fertil Steril. 2010;93(5):1388-93.

27. Ogbeche KA, Ogunbiyi YO, Duru FIO. Effect of methanol extract of Kigelia africana on sperm motility and fertility in rats. Nigerian J Health Biomed Sci. 2002;2:113-6.

28. Howell SJ, Shalet SM. Effect of cancer chemotherapy on the pituitarytesticular axis. Int J Androl. 2002;25:269-76.

29. Atessahin A, Sahna E, Turk G, Ceribasi AO, Yilmaz S, Yuce A, Bulmus O. Chemoprotective effect of melatonin against cisplatin-induced testicular toxicity in rats. J Pineal Res. 2006;41:21-7.

30. Zahra K, Shahrbanoo O, Ali G, Mozafar K. Protective effect of Tribulus terrestris hydroalcoholic extract against cisplatin-induced cytotoxicity on sperm parameters in male mice. Int J Morphol. 2014;32(2):551-7.

31. Amin A, Hamza AA, Kambal A, Daoud S. Herbal extracts counteract Cisplatin-mediated cell death in rat testis. Asian J Androl. 2008;10(2):291-7.

32. Turk G, Atessahin A, Sonmez M, Ceribas AO, Yuce A. Improvement of cisplatin-induced injuries to sperm quality, the oxidant-antioxidant system, and the histologic structure of the rat testis by ellagic acid. Fertil Steril. 2008;89:1474-81.
33. Aitken RJ. Free radicals, lipid peroxidation and sperm function. Reprod Fertil Dev. 1995;7:659-68.

34. Otitoloju AA, Obe IA, Adewale OA, Otubanjo OA, Osunkalu VO. Preliminary study on the reduction of sperm head abnormalities in mice, Mus musculus, exposed to radiofrequency radiations from global system for mobile communication base stations. Bull Environ Contam Toxicol. 2010;84:51-4.

35. Sebastian R, Raghavan SC. Endosulfan induces male infertility. Cell Death Dis. 2015;6:20-2

36. Joshi SC, Mathur R, Gulati N. Testicular toxicity of chlorpyrifos (an organophosphate pesticide) in albino rat. Toxicol Industr Health. 2007;23: 439-44.

\section{Publisher's Note}

Springer Nature remains neutral with regard to jurisdictional claims in published maps and institutional affiliations.

\section{Submit your manuscript to a SpringerOpen ${ }^{\circ}$ journal and benefit from:}

- Convenient online submission

- Rigorous peer review

- Open access: articles freely available online

- High visibility within the field

- Retaining the copyright to your article

Submit your next manuscript at $\boldsymbol{\nabla}$ springeropen.com 